\title{
Monumental burials and memorial feasting: an example from the southern Brazilian highlands
}

\author{
José Iriarte ${ }^{1}$ J. Christopher Gillam² \& Oscar Marozzi ${ }^{3}$
}

What happened at the sites of prehistoric burial mounds after they were erected? In the southern highlands of Brazil and Argentina the pre-Hispanic mounds of the twelfth-thirteenth centuries $A D$ are surrounded by large circular enclosures with avenues leading to their centre. The authors discovered that the banks of the surrounding enclosure were built up over several generations of time, accompanied by a succession of ovens. Ethnohistoric observations of more recent peoples in the same region suggested an explanation: the cremation of a chief was followed by periodic feasts at his mound, where meat was steamed and maize beer prepared at the edge of the gathering.

Keywords: Argentina, Brazil, pre-Hispanic period, Taquara/Itararé, Kaingang, emergent complexity, public architecture, burial mounds, ceremonial enclosures, feasting

\section{Introduction}

Anthropologists and archaeologists studying the Neolithic in the Old World and Formative periods in the Americas have long been concerned with the study of the relationships between the living and the dead and in particular with the social and ideological roles of monumental burial and the appreciation and use of these burial monuments by successor societies (Fleming 1973; Beck 1995; Dillehay 1995; Barrett 1996). Debate has been focused on the way that the arrival of monumental burial practices reflected changes in subsistence, population growth, ranking and inheritance, territoriality, and ideology (e.g. Renfrew 1973; Bradley 1998; Carr \& Case 2005; Dillehay 2007).

The southern Brazilian highlands features a pre-Hispanic culture of monumental earthwork construction, the Taquara/Itararé tradition, which includes both mounds and causewayed enclosures (Beber 2005). This is also one of the few regions in the world where indigenous mound-building and associated ceremonies have been recorded in a living people, the Kaingang (Métraux 1946). Comparison with the pre-Hispanic and the later practice may help us understand the role that burial monuments and post-funerary rites played in the emergence of complex societies more generally.

1 Department of Archaeology, University of Exeter, Laver Building, North Park Road, Exeter, EX4 4QE, UK (Email:J.Iriarte@exeter.ac.uk)

2 Savannah River Archaeological Research Program, South Carolina Institute of Archaeology and Anthropology, University of South Carolina, 1321 Pendleton Street, Columbia, SC 29208, USA

3 SAR, Servicios Arqueológicos, Uruguay

Received: 11 December 2007; Accepted: 27 February 2008; Revised: 8 April 2008

ANTIQUITY 82 (2008): 947-961 
This paper presents a synthesis of the Taquara/Itarare earthen monument tradition based upon recent investigations at the ElDorado mound and causewayed enclosure complex, PM01, in north-eastern Argentina. These are interpreted in light of procedures for the burial of a chieftain, as observed among the later Kaingang cultural tradition.

\section{The Taquara/Itararé tradition and the arrival of mound and enclosure complexes in the southern Brazilian highlands}

The Taquara/Itararé tradition (Beber 2005) otherwise the pre-Hispanic southern Jê (Noelli 2000; 2005) extends along the southern Brazilian states of Paraná, Santa Catarina and Rio Grande do Sul and the adjacent Misiones Province, Argentina, and Paraguay (Figure 1). Dating back to $c .220 \mathrm{BC}$, and possibly to $2860 \mathrm{BC}$ (De Masi 2006), this culture is characterised by its diagnostic ceramics, highland pit-house villages, a mixed collective economy including Araucaria seeds, horticulture, hunting and fishing, and elaborate earthen mound and enclosure complexes (see Beber 2005 for a more detailed summary).

The earth monuments are located on hill-tops or ridges commanding wide views. Locally called danceiros (dance grounds) in Brazil, the enclosures are characterised by circular, elliptical and key-hole shape plans (Figure 2). The banks are typically 3-6m wide and the enclosures $20-180 \mathrm{~m}$ in diameter. They may exhibit associated small ringworks, and their remains rise to between 30 and $80 \mathrm{~cm}$. Most earthen enclosures contain central mounds (1.5-20m diameter; $0.7-3 \mathrm{~m}$ high), typically raised over a cremated burial of a single adult person associated with few lithics or ceramic sherds (Figure 3 shows an example). However, central mounds containing several interments have also been reported (De Masi 2005). The formal layout of these enclosures, and the lack of substantial domestic debris within them, indicate that they were ceremonial spaces. In some regions, mound and enclosure complexes occur together in small groups such as at ElDorado, Anita Garibaldi, Campos Novos, and in the Pinhal da Serra regions. In the latter, their distribution on the landscape suggests that they are placed at nodal points along regional transit routes (Saldanha 2005; Copé 2007).

Radiocarbon dates suggest the construction of these monuments coincides with a more intense late Holocene occupation of the southern Brazilian highlands by Taquara/Itararé groups (Table 1; Iriarte \& Behling 2007: Figure 7). The genesis of this monumental tradition that peaked after $\mathrm{AD} 1000$ took place in a time when regional cultures were flourishing, populations as reflected in the number of sites were increasing, more intensive ways of food-production were developing and long-distance population migrations over contested territories were taking place across lowland South America. We shall return to this topic in the final section of the article.

\section{Recent excavations at ElDorado mound and enclosure complex}

We carried out two field seasons of geophysical survey and excavations at a complex of earthworks in the vicinity of ElDorado city (Misiones Province, Argentina) that spread over 200ha and had once consisted of eight circular enclosures, two of which contain central mounds (Menghin 1957; Wachnitz 1984). Site PM01, the largest and best preserved of these enclosures is located on a promontory with a panoramic view of its surroundings. 


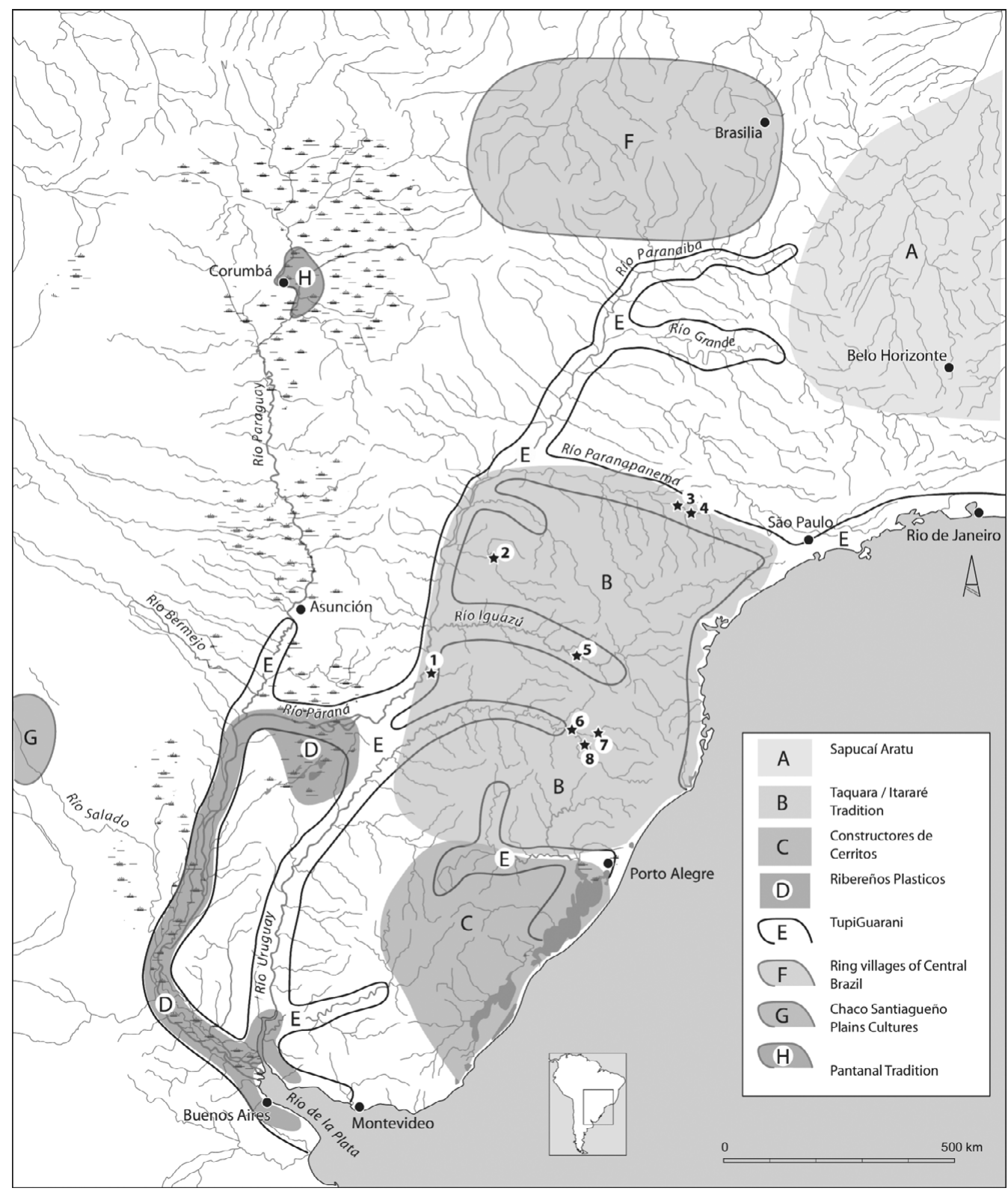

Figure 1. Map showing approximate locations of major archaeological traditions in south-eastern South America during the late Holocene, and the TaquaralItarare mound and enclosure complexes discussed in the text. Key: 1. PMO1 ElDorado; 2. PR-UB-4 Ubirata; 3. SP-IP-8 Itaberá; 4. T3Q1N8, SP, Areia Branca; 5. PR-MN-4 Uribici; 6. SC-AG-12 Campos Novos; 7. SC-AG-99 and SC-AG-98 Anita Garibaldi; 8. RS-PE-21 Pinhal da Serra and RS-PE-31 Esmeralda.

PM01 is characterised by a central mound (20m in diameter and $3 \mathrm{~m}$ high) located on the highest ground of the hill facing a smaller mound ( $10 \mathrm{~m}$ diameter) located $45 \mathrm{~m}$ to the south-east (Figure 4). Framing the mounds there is a $180 \mathrm{~m}$-diameter circular earthen 


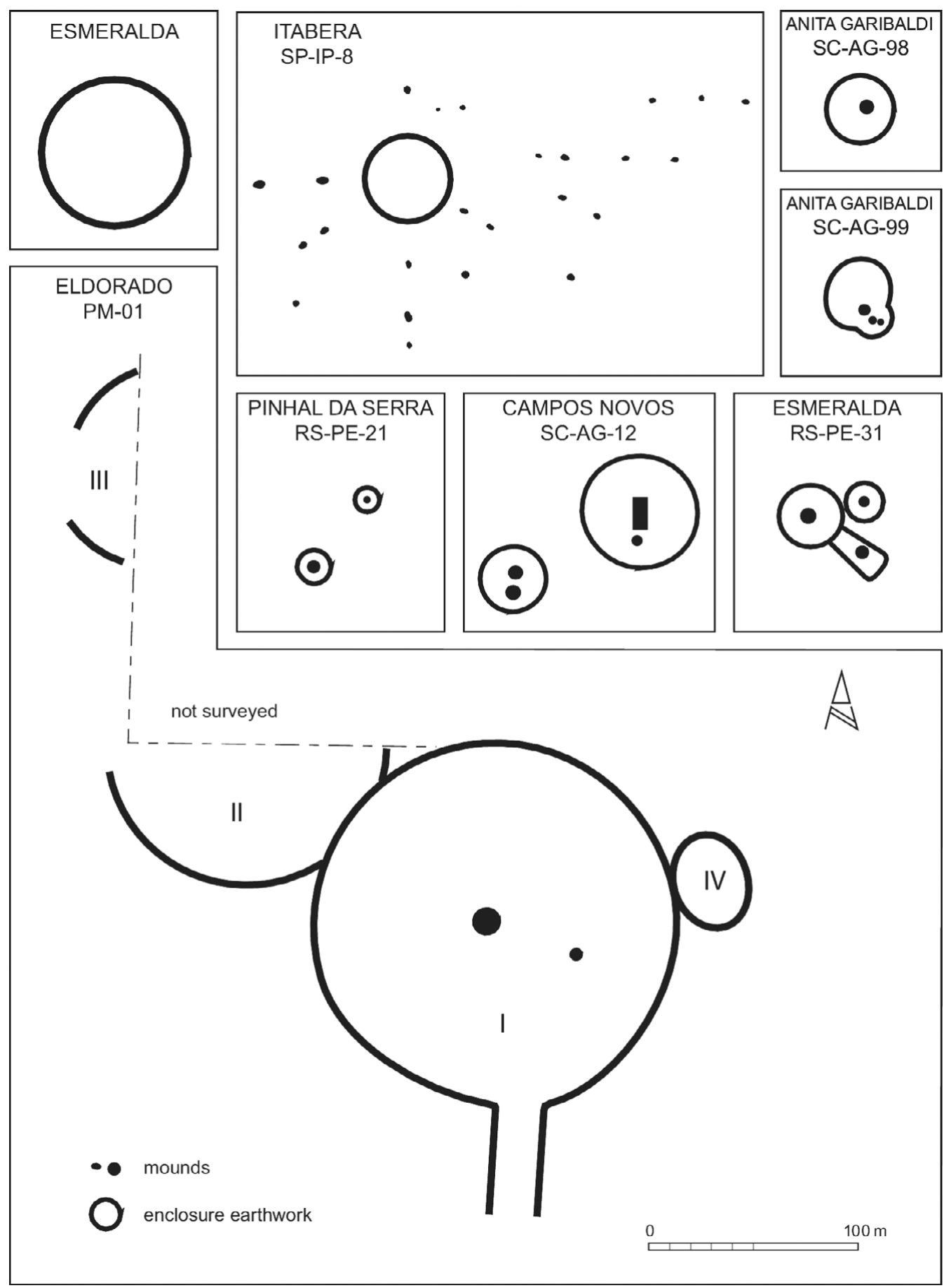

Figure 2. Mound and enclosure complexes from south-eastern Brazil and Argentina. (Esmeralda and RS-PE-31 (Schmitz \& Becker 1991: 293); SP-IP-8 Itaberá (Chmyz et al. 1968: 19); SG-AG-98 and SC-AG-99 Anita Garibaldi (De Souza 2007); RS-PE-21 Pinhal da Serra (De Souza 2007); SC-AG-12 Campos Novos (De Masi 2005: 233); PM01 ElDorado (Wachnitz 1984: 207)). 


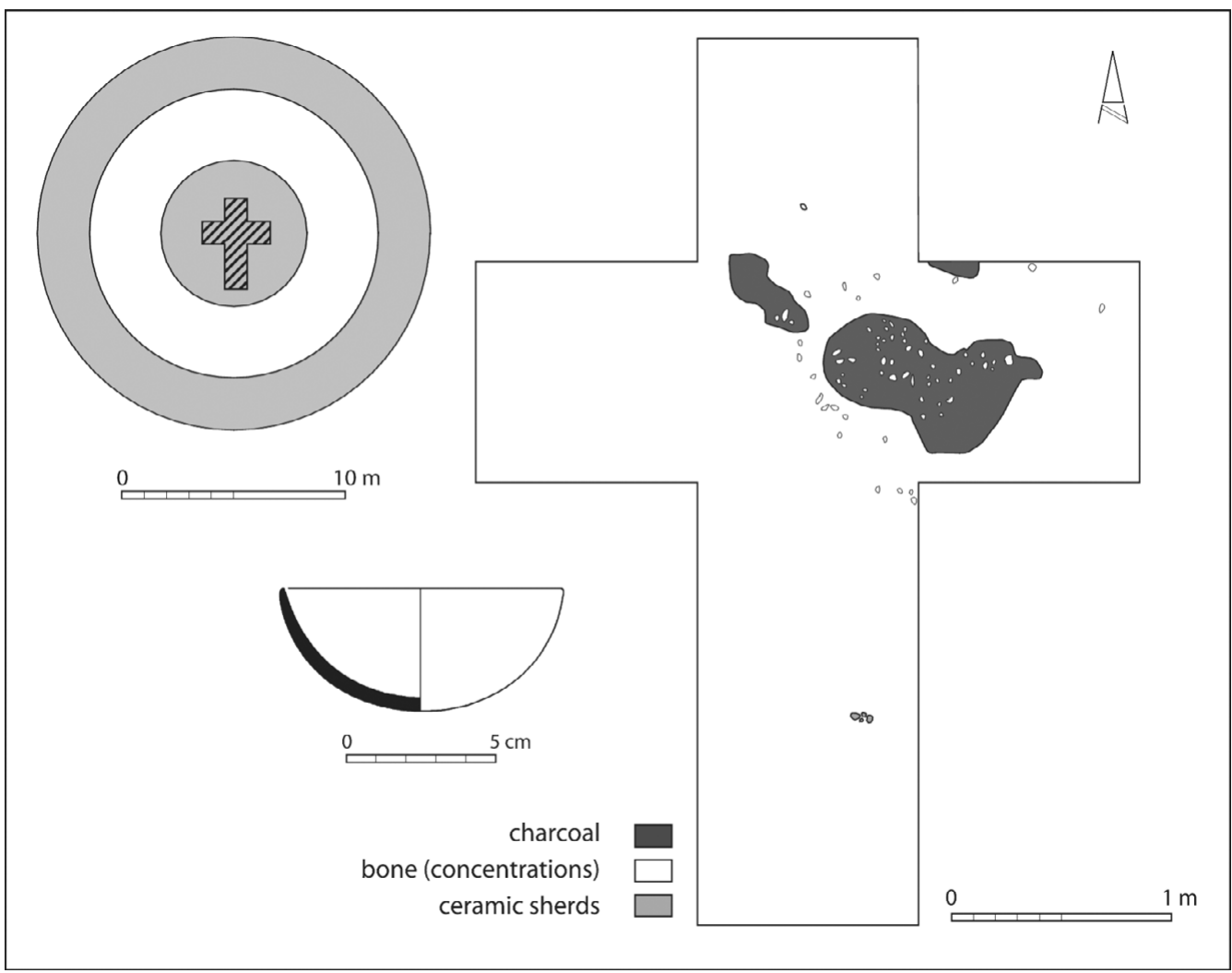

Figure 3. The mound RS-PE-21 explored with a cruciform trench revealed a pyre with human bone near its centre (modified from De Souza 2007: Figure 3).

embankment (with banks $6 \mathrm{~m}$ wide and $30-40 \mathrm{~cm}$ high), called Circle I, that was connected to a $400 \mathrm{~m}$-long and $18 \mathrm{~m}$-wide avenue marked by parallel earthen embankments (Figure 5). This formal entrance may have served to emphasise orientation and lead actors through a causeway that ascends $30 \mathrm{~m}$ to the mound at the top of the hill. The northern opening suggests that people entered the enclosure by the southern avenue, passed through the plaza between the mounds and departed through a northern exit. On the western side of the ring, there are two smaller connecting earthen rings, whose diameters could be estimated as lying between 130 and $90 \mathrm{~m}$. A smaller elliptical-shaped ring $(c .35 \times 45 \mathrm{~m})$, Circle IV, is located on the eastern side of the site. Most parts of Circle I are $30-40 \mathrm{~cm}$ high, but reach $70 \mathrm{~cm}$ where it meets Circle II. Today, only the central mound and portions of the primary ring enclosure are preserved. The layout resembles other Taquara/Itararé mound and enclosure sites, where circles are generally aligned NW-SE or SW-NE and with the largest structures always located in the western sector of sites (De Souza 2007).

Previous excavation by Menghin and his collaborators (1957) did not reveal any features or sequential layers in the mound, but Wachnitz (1984: 174) described a darker shallow basin pit feature at the very base of the mound, which probably represents a human burial. Menghin's excavations at the edge of Circle I, where it meets Circle II, revealed several 
Table 1. Taquara/Itararé mound and enclosure complexes dates from the Brazilian states Rio Grande do Sul (RS), Santa Catalina (SC), Paraná (PR) and Misiones Province (MS), Argentina. The calibration of the radiocarbon dates have been carried out after CALPAL (Weninger $e t$ al. 2004).

\begin{tabular}{|c|c|c|c|c|c|c|}
\hline $\begin{array}{l}\text { Provenance } \\
\text { Site }\end{array}$ & Locality & Lab no. & ${ }^{14} \mathrm{C}$ age (yr BP) & $68 \%$ range (cal $\mathrm{BP})$ & Calendric age (cal AD) & Reference \\
\hline PR-UV-11 & Cruz Machado, PR & SI 1010 & $680 \pm 70$ & $576-684$ & $1320 \pm 54$ & Chmyz et al. 2003 \\
\hline PR-UB-4 & Ubirita, PR & SI 2192 & $470 \pm 95$ & $375-594$ & $1465 \pm 109$ & Chmyz et al. 2003 \\
\hline PR-UB-4 & Ubirita, PR & SI 2193 & $855 \pm 95$ & $714-890$ & $1148 \pm 88$ & Chmyz et al. 2003 \\
\hline PR-MN-4 & Ubirita, PR & SI 6396 & $595 \pm 60$ & $555-643$ & $1351 \pm 44$ & Chmyz et al. 2003 \\
\hline PM01 & ElDorado, MS & Beta 221418 & $760 \pm 60$ & $672-747$ & $1240 \pm 37$ & Iriarte et al. 2007 \\
\hline PM01 & ElDorado, MS & Beta 237106 & $760 \pm 40$ & $680-726$ & $1247 \pm 23$ & Iriarte et al. 2007 \\
\hline PM01 & ElDorado, MS & Beta 237105 & $720 \pm 40$ & 655-697 & $1274 \pm 21$ & Iriarte et al. 2007 \\
\hline PM01 & ElDorado, MS & Beta 221417 & $480 \pm 60$ & $478-558$ & $1382 \pm 40$ & Iriarte et al. 2007 \\
\hline RS-AN-03 & Pinhal da Serra, RS & Beta 166588 & $1000 \pm 40$ & $843-951$ & $1053 \pm 54$ & Copé \& Saldanha 2002 \\
\hline SC-AG-12 & Campos Novos, SC & Beta 190304 & $600 \pm 40$ & $562-641$ & $1348 \pm 39$ & DeMasi 2005 \\
\hline SC-AG-12 & Campos Novos, SC & Beta 185442 & $430 \pm 40$ & $443-515$ & $1471 \pm 36$ & DeMasi 2005 \\
\hline SC-AG-12 & Campos Novos, SC & Beta 185443 & $690 \pm 40$ & $580-676$ & $1322 \pm 48$ & DeMasi 2005 \\
\hline SC-AG-12 & Campos Novos, SC & Beta 185444 & $470 \pm 40$ & $502-535$ & $1431 \pm 16$ & DeMasi 2005 \\
\hline SC-AB-96 & Abdon Batista, SC & Beta 190303 & $360 \pm 40$ & $344-475$ & $1540 \pm 65$ & DeMasi 2005 \\
\hline SC-AG-75 & Campos Novos, SC & Beta 190309 & $980 \pm 40$ & $828-933$ & $1069 \pm 52$ & DeMasi 2005 \\
\hline SC-AG-77 & Campos Novos, SC & Beta 190311 & $420 \pm 40$ & $380-510$ & $1505 \pm 65$ & DeMasi 2005 \\
\hline SC-CR-06 & Celso Ramos, SC & Beta 190312 & $220 \pm 40$ & $146-299$ & $1727 \pm 76$ & DeMasi 2005 \\
\hline T3Q1N8 & Areia Branca 6, SP & Beta 135824 & $1530 \pm 40$ & $1379-1495$ & $513 \pm 58$ & DeBlasis Pers. Comm. 2007 \\
\hline T3Q1N8 & Areia Branca 6, SP & Beta 124752 & $1430 \pm 60$ & $1306-1388$ & $603 \pm 41$ & DeBlasis Pers. Comm. 2007 \\
\hline
\end{tabular}




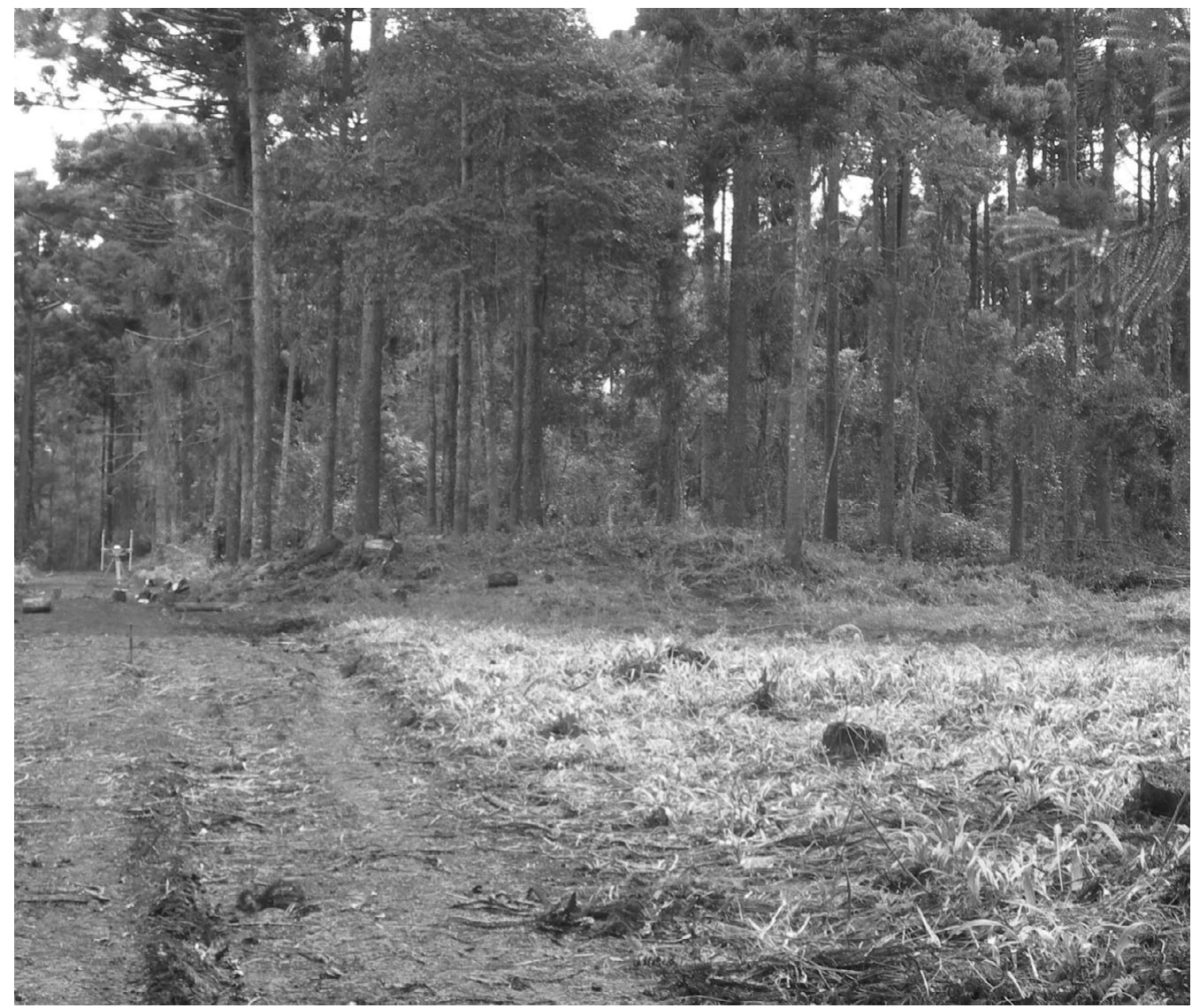

Figure 4. Central mound of site PMO1, looking east.

discrete circular, oval and elongated stone clusters, spaced 30 to $50 \mathrm{~cm}$ apart under the bank (Menghin 1957: 33; Wachnitz 1984: 173). Similar features were located by our excavations. A $6 \times 1 \mathrm{~m}$ trench and several extensions totalling $15 \mathrm{~m}^{2}$ in the same northwest sector of the bank showed several phases of construction. Beneath the bank were two circular clusters of pebbles, overlaying a charcoal layer and associated with burnt clay, a few unidentifiable burnt bones, sherds and lithics (Figure 6). This was followed stratigraphically by several construction stages interspersed with occupation phases, including hearths and small clusters of disaggregated stones associated with charcoal and culminating in a stone cluster of elliptical shape $(2 \times 1 \mathrm{~m})$. These strata gave a sequence of radiocarbon dates centring in the early to mid-thirteenth century AD. Test excavations in Circle IV revealed smaller, less compacted stone clusters dating to the same period. Another succession of stone clusters was defined on the opposite, eastern side of Circle I, with a radiocarbon date centering on the later fourteenth century. All stone clusters were embedded in sediments with charcoal and burnt earth.

In all sectors of the bank excavated, scatters of refuse were located beyond the bank, implying an intention to keep the enclosure's interior clean. The stone clusters are not 


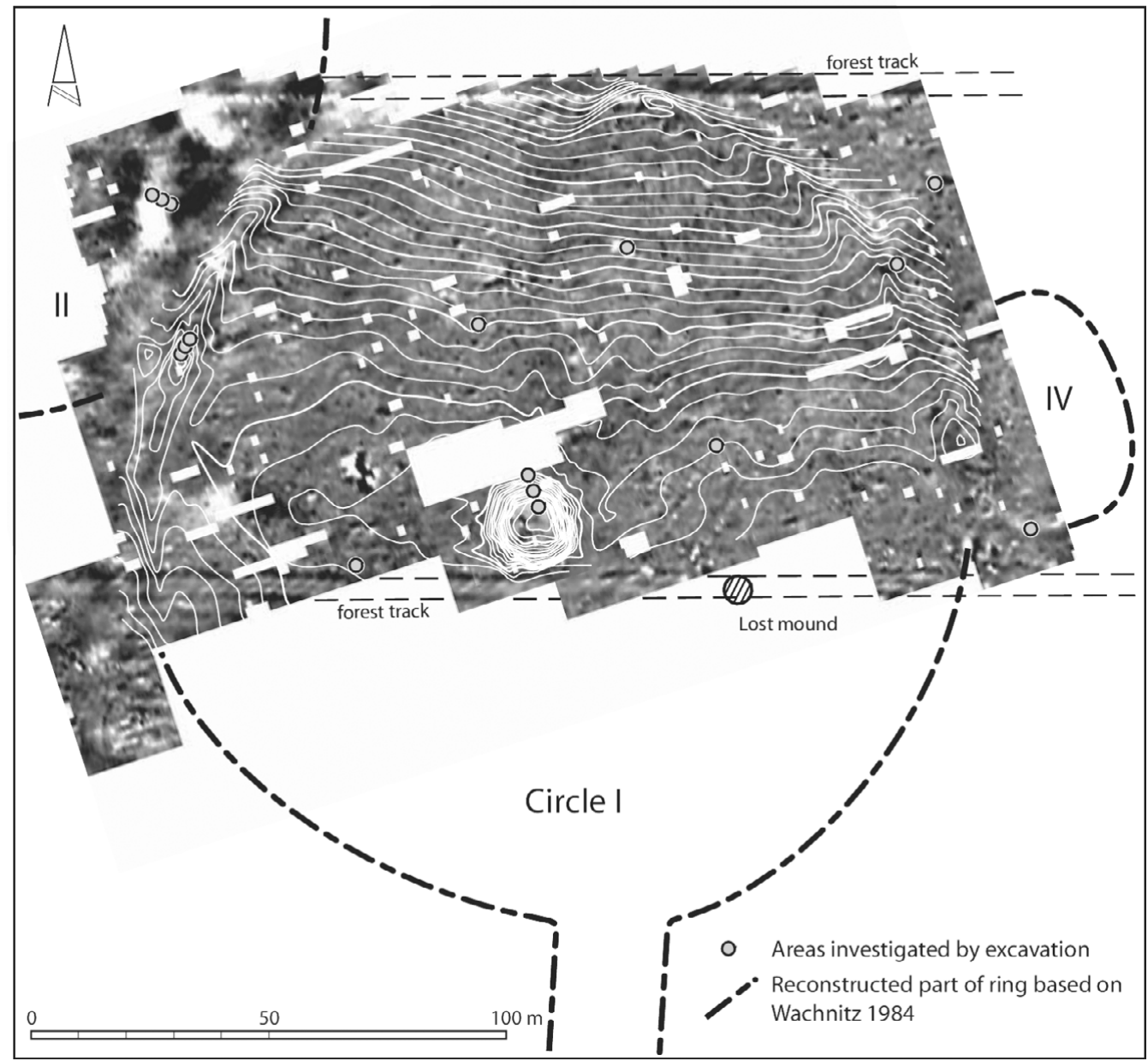

Figure 5. Combined geophysical and topographic map of site PM01. Reconstructed parts of the site are based on Wachnitz (1984: 207).

restricted to the lowest parts of the earthen embankment, but are found throughout the stratigraphic sequence and appear to mark discrete episodes of construction. The radiocarbon dates suggest that the construction of Circle I was broadly contemporary with Circle IV. A comparison of the dates on the western and eastern sectors of Circle I demonstrates that the embankment was used for at least 135 years. Collectively, the evidence suggests that Circle I grew in several episodes associated with the successive laying of stone clusters.

Ceramics recovered at site PM01 generally resemble Taquara/Itararé tradition ceramics (Beber 2005). Similar to reconstructed vessel forms recovered from other mound and enclosure complexes in the southern Brazilian Highlands (Saldanha 2005), they are small, shallow bowls representing drinking or serving cups (Figure 7) (Iriarte et al. 2007). Phytolith analysis from charred residues of four ceramic sherds associated with the stone clusters document the presence of maize cob phytoliths, suggesting these ceramics were used to drink maize-based beverages (Iriarte n.d.). 


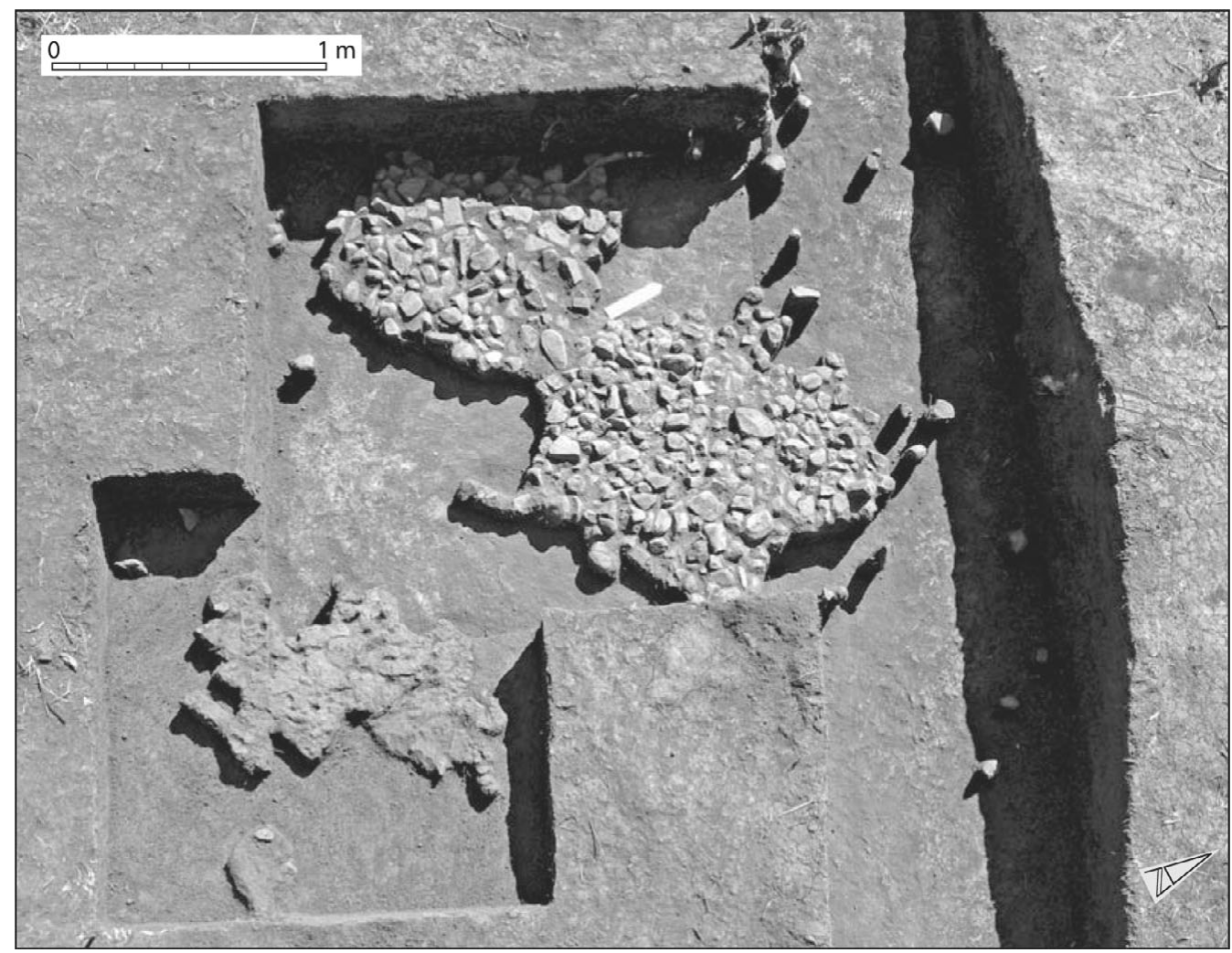

Figure 6. Excavation photograph of TW01 central sector showing superimposition of features including the stone clusters and hearth.
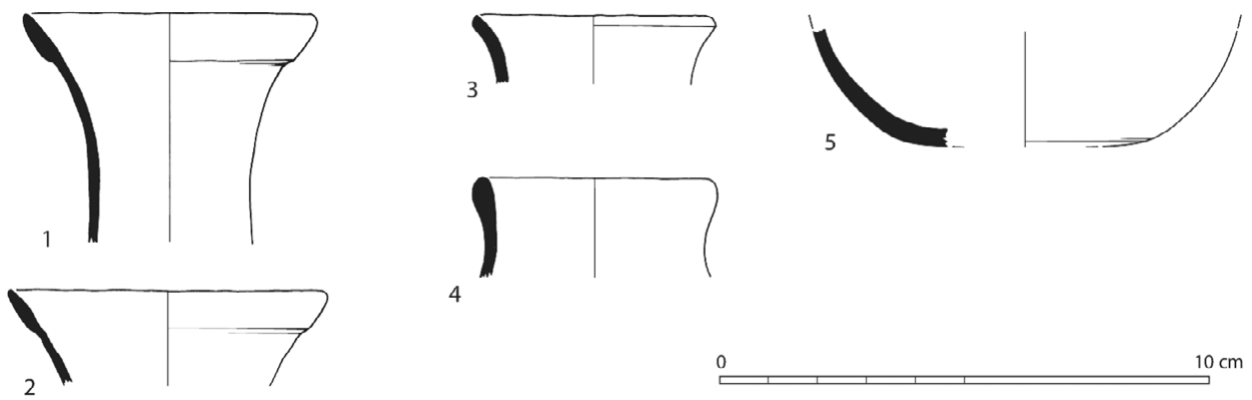

0 $10 \mathrm{~cm}$

Figure 7. Sample of ceramic vessel shapes recovered from TW01 and TE01 trench transects in Circle I.

\section{Ethnographic analogy: burial rites among the Kaingang}

At the time of European contact, Kaingang and Xokleng groups belonging to the MacroJê linguistic stock and, more specifically, to the languages of the Akwen (Xakriabá, Xavante, Xerente) and the Apinayé in the states of Minas Gerais, Mato Grosso and Goiás (Noelli 
2000; 2005: 178) inhabited the southern Brazilian highlands. The ethno-historic record of Kaingang mortuary practices in the nineteenth and early twentieth centuries have been previously used to interpret these archaeological sites as ceremonial spaces, where geographically dispersed groups came together to bury an important chief (e.g. Chmyz \& Sauner 1971; Copé \& Saldanha 2002).

When a Kaingang chief died, his subordinates were notified and appeared in the house of the dead chief. The elder chiefs usually carried the dead body to the place of burial. Paula (1924: 126) noted that they dug a shallow pit there and buried the dead man with his belongings (bow, arrows, clothes and axe). Metraux (1946: 465) on the other hand states that they destroyed part of the property of the deceased and imposed a strict taboo on his name. Mabilde (1983: 108-16) recounts that they put a vessel close to the head, which was oriented to the east and then lit a fire on the western side of the body. Other descriptions mention that they constructed a wood shaft or covered the body with palm leaves (Maniser 1930: 781). Schaden (1958) also described how Xokléng groups cremated bodies before interment. People from different tribes came to the funeral and formed a circle surrounding the deceased (Métraux 1946). After a collective expression of lament the corpse of the deceased was covered with earth and his eldest son proclaimed the new chief. They made honey wine and invited neighbours to build the mound by carrying dirt loads in baskets until the mound attained a pyramidal shape. After the interment of the body and the construction of the mound, the burial place was periodically visited to clean the area of vegetation and to remember the dead with lamentation, dancing, songs and drinking. Baldus (1937: 49) notes that these large gatherings took place in autumn between April and June when maize is ripe and Araucaria seeds are ready to collect.

In terms of political organisation, the account of Mabilde (1983) indicates that there were main chiefs and subordinate chiefs. Some big chiefs like the Cacique Braga were reported to be in command of 23 tribes (Becker 1976: 111). Mabilde's account (1983) also indicates that the construction of a mound was reserved for big chiefs, while the funerary rites associated with subordinated chiefs were far simpler. The deposition of personal weaponry as grave goods suggests that these were possibly renowned war leaders. In addition, the transfer of the chiefly office to the dead chief's eldest son during the burial ceremony indicates an inheritance of the chiefly office. Overall, these historic records point to an established, moderate degree of political complexity in the Kaingang.

There are many common features between the historically recorded Kaingang burial practices and the archaeological record. Most mounds systematically excavated exhibit human remains at its base accompanied by ceramics and lithics. A lack of stratification in the mounds also points to a single construction episode, like the one described in the historic accounts. In addition, the fact that neighbouring tribes gathered around the burial mounds in circles is reminiscent of the circular earthen embankments found in many sites and a semicircular arrangement of stone clusters found surrounding the central mound of site SC-AG-12 (De Masi 2005). The orientation of the avenue is also probably related to burial position and astronomical observations. Last but not least, the presence of dual patterns in public architecture, such as the presence of paired mounds and their associated minor ringworks may be the material representation of the dual social organisation characteristic of these Jê societies (Maybury-Lewis 1974; 1979) (e.g. sites RS-PE 21, 31, SC-AG-12 and PM01). 
Despite these underlying similarities, the Taquara/Itararé archaeological mound and enclosure complexes and the circumstances in which they arose are very different from the historically reported ones. The pre-Hispanic mound and enclosure complexes are far more complex and elaborated than the ones recorded from the historic Kaingang groups, profoundly transformed as a result of the European colonisation of the region.

\section{Discussion}

We interpret the history of site PM01 as a funerary monument where an important chief was buried under the central mound in a single event followed by multiple feasting activities over several generations. Our interpretation of the stone clusters under the banks of the enclosure features differs markedly from that of Menghin (1957: 33) who suggested that the stone clusters represented a sacred fence, which was later replaced by an earthen embankment, on top of which a palisade was built. We interpret them rather as earth ovens. The size, discreteness and compactness of the stone clusters, in addition to the layer of charcoal within and below them, and the recovery of burnt bones seems to be the result of earth ovens for cooking meat similar to the ones described ethnographically for the Kaingang by Métraux (1946: 452-3). According to his account, an 'earth oven serves for baking large slices of meat, for example, tapir. A large pit is dug in the ground and lined with stones. A fire is built within the hole until the stones are glowing. The ashes and embers are then removed, the stones are covered with leaves, and the meat, carefully wrapped, is placed inside and buried under a thick layer of soil. Twelve hours later the meat is taken out, perfectly cooked'. Cooking meat in earth ovens by steaming has also been documented among several Central Brazilian Jê groups including the Apinayé (Nimuendajú 1939: 95-6), the Kayapó (Dreyfus 1972: 26-7), the Mekranoti (Werner 1984: 104-5) and the Serente (Nimuendajú 1942: 34). Both Dreyfus (op.cit.) and Nimuendajú (1942) indicate that cooking by steaming with stones is due to a lack of large boiling cooking vessels. It is no coincidence that none of the ceramics recovered at the site are suitable for cooking by boiling.

Though not all Jê groups consume intoxicating beverages, the consumption of fermented alcoholic beverages is widely reported in Kaingang historical accounts. Métraux (1946: 465 ) indicates that the mourning of the dead was followed by a beer festival accompanied by dances and songs. Noelli (2000: 243) mentions the consumption of kifé, a fermented alcoholic beverage based on maize and honey among the Kaingang in profane collective feasting and the consumption of kiki a honey-based, fermented beverage during the annual homage to the dead. Maize was a crucial ingredient for many ritual foods among Jê groups, such as the Suyá, for whom the ripening of corn was closely associated with the beginning of the ritual period (Seeger 1981: 44). Overall, the ceramic, botanical and ethnohistoric evidence suggests that these small vessels were used to drink a maize-based beverage.

Feasting with meat and maize is a pervasive feature of Jê societies. As Maybury-Lewis (1974: 42) noted the Shavante, in common with other Gê tribes, value meat and maize as the basis of all ceremonial presentations. The vast plaza area, the numerous earth ovens accumulated through time and their associated ceramics, suggest that large numbers of participants came together regularly at this notable ritual structure to feast on meat delicacies 
and maize beverages associated with post-burial funerary practices. To paraphrase Rebecca Saunders (2004), it seems that the circular earthen embankments at site PM01 represent 'consumption made conspicuous. These mound and enclosure complexes were places where people returned periodically to mourn the dead, dance, eat and drink. These festivals were likely sponsored by the lineage descendants of the chief buried in the central mound. Circle I with a south-north orientation marked by the entry causeway may have been used as an observatory to monitor the passage of the sun or other celestial bodies as a means of clocking agricultural and ritual cycles.

To understand the emergence of this monumental tradition, we need to look at the broader picture of what was happening in lowland South America during the late Holocene. At this time, many regions of lowland South America were experiencing population growth, regional integration, a marked increase in monumental activity, appearance of fortified settlements, the development of ceramic styles and long-distance population migration and displacement. This is also a time when lowland societies began to transform the landscape at a scale not seen before. Raised-field systems in seasonally-flooded savannas and dark earth soils associated with intensive agriculture appeared along the bluffs of major rivers in Amazonia and its periphery (e.g. Denevan 2001; Iriarte 2007). During this time, the Rio de la Plata Basin was a passageway that linked major zones of ecological diversity and cultural complexity. It represented a geographical enclave where major cultural traditions from tropical regions like the Tupi-Guarani (Brochado 1984; Noelli 1998; Prous 1992), the Arawak-Ribereños Plásticos (Nordenskiöld 1930; Métraux 1934) and the southern Jê (Noelli 2000) converged and interacted. These groups had arrived in the region by at least AD 1 and became well-established after AD 1000 along forested areas following major river courses and the southern Brazilian plateau. In other areas, archaeological evidence indicates that by $\mathrm{AD} 1000$ groups were organised at a regional level, became more territorial, adopted more intensive food-production practices and monument construction reached its peak. Examples include the Central Brazilian (Wüst \& Barreto 1999 ) and Sapucaí/Aratu tradition (Prous 1999) ring villages, the Pantanal ceramic moundbuilding cultures (Schmitz et al. 1998), the Middle and Late Period mounded villages of the Chaco-Santiagueño Plains (Ottonelo \& Lorandi 1987) and the 'Costructores de Cerritos' along south-eastern Brazil and Uruguay (López 2001; Criado et al. 2006; Iriarte 2006).

It is in this highly-contested ethnic arena that the Taquara/Itararé mound and enclosure monument tradition developed. The emergence of the monumental tradition and the elaboration of ceremonial conduct represent an eloquent sign of the social needs of communities whose territory and contacts were increasing. Kossok's cross-cultural finding showing that burial monuments as 'display graves' tend to be built during times of excessive cultural contact, or a period of military, social or political change is particularly appropriate for our case study (1974 in Dillehay 1995: 285). Ritual feasting often has significant social, economic and political role. It may serve to promote social integration and cohesion (e.g. Dillehay 2004), but also may encourage exclusion, appropriation and inequality (Dietler 2001). These ceremonial centres represent permanently designated sacred spaces that must have played a major role in the social and territorial stability of Taquara/Itararé groups. The post-burial gatherings associated with feasting that took place at site PM01 were political 
events that at a large scale may have served to promote inter-village solidarity and military interdependence among Taquara/Itararé groups at a time of increased inter-group contact. These ritual sites may have also functioned as neutral places to resolve conflicts, foster reciprocity and forge alliances among groups.

\section{Conclusion}

The Taquara/Itarare earthworks are ceremonial places, where a leader is buried and power is subsequently played out by aspiring social actors (Kertzer 1988). The ethnohistory of the Kaingang has proved helpful in their interpretation. As indicated by Dillehay (1995: 285) for the Araucanian and ethnographic case studies, the burial of an important chief and the associated funerary practices are events when political succession takes place, a new leader is established and the deceased could be transformed into an authentic ancestor. These are times to legitimise and consolidate the authority of chiefs, maintain old alliances and build new ones.

No doubt, as more information becomes available on the archaeology of the Rio de la Plata Basin and its adjacent littoral zone, we will come to realise better how the elaboration of the different features of these Taquara/Itararé mound and enclosure complexes were related to more subtle socio-political changes. For example, what factors account for the variability in site size and layout? What were the uses and construction histories of circular enclosures that lack mounds and/or causeway entrances? What do mounds that contain several interments represent? Similarly, what determined the number of mounds that were built in particular areas across the southern Brazilian highlands? How do settlement patterns relate to monumental architecture? Future work at a regional level will be able to clarify the picture of settlement variability, allowing a more precise understanding of the role that PM01 played in the emergence of early Formative societies in the region, and by extension the role that such monuments played in societies undergoing similar transitions beyond South America.

\section{Acknowledgments}

We wish to thank the Dirección General de Patrimonio Cultural y Museos del Gobierno de la Provincia de Misiones, Ruth Poujade and Julia Argentina Perié for granting us permission to carry out investigations in ElDorado, Misiones. Research at site PM01 was funded by grants from the National Geographic Committee for Research and Exploration (CRE 7853-05) and the University of Exeter Exploration Fund. We also received support from the Department of Culture of the Municipality of ElDorado who provided us with accommodation, logistics and warm hospitality. We thank an anonymous reviewer, Francisco Silva Noelli, Fernando Santos Granero and Tom Dillehay for insightful comments on the manuscript. The manuscript greatly benefited from the editorial work of Martin Carver. Paulo DeBlasis is acknowledged for providing us with unpublished data. We also want to thank many people who collaborated with us during different stages of the project. The guidance of Dr Jorge Rodríguez and the help and enthusiasm of José Gerardi was invaluable in the first steps of this project. In ElDorado, we want to specially thank Juan Ernesto Aumer, Paola Bacalini, Margarita Kummerer, Roman Ríos, Eduardo Stirnemann and Pamela Cooper de Colcombet. We are also grateful to Jorge Saucedo who carried out the topographical survey of the site. Seán Goddard drafted all the figures present in this article. Last but not least, we are grateful to the many students from the Universidad Nacional de Misiones and the University of Exeter who participated in the fieldwork. 


\section{Monumental burials and memorial feasting}

\section{References}

BALDUS, H. 1937.Ensaios de etnologia brasileira. São Paulo: Companhia Editorial Nacional.

BARRETT, J. 1996. The living, the dead and the ancestors: Neolithic and Early Bronze Age mortuary practices, in R. Preucel \& I. Hodder (ed.) Contemporary archaeology in theory: 394-412. London: Blackwell.

BRADLEY, R. 1998. The significance of monuments on the shaping of human experience in Neolithic and Bronze Age Europe. London: Routledge.

BeBER, M.V. 2005. O sistema do asentamento dos grupos ceramistas do planalto sul-brasilero: o caso da Tradição Taquara/Itararé, in Arqueologia no Rio Grande do Sul, Brasil (Documentos 10): 5-125. São Leopoldo, Brazil: Instituto Anchietano de Pesquisas, UNISINOS.

BECK, L.A. 1995. Regional approaches to mortuary analysis. London: Plenum.

Becker, I.I. 1976. O Indio Kaingang no Rio Grande do Sul. São Leopoldo, Brazil: Universidade do Vale do Rio dos Sinos.

Brochado, J.P. 1984. An ecological model for the spread of pottery and agriculture into Eastern South America. Unpublished dissertation, University of Illinois.

CARR, C. \& T. CASE. 2005. Gathering Hopewell: society, ritual and ritual interaction. New York: Springer.

ChmyZ, I. \& Z.C. SAUNer. 1971. Nota prévia sobre as pesquisas arqueológicas no vale do rio Piquiri. Dédalo 13: 7-36.

Chmyz, I., C. Perota, H.I. Mueller \& M.L. Fleury DA RoCHA. 1968. Nota sôbre a arqueologia do vale do Rio Itararé. Revista do Centro de Ensino e Pesquisas Arqueológicas 1: 7-23.

Chmyz, I., E. Bora, R. Santos Ceccon, M.E. SGANZERLA \& J.E. VOLCOV. 2003. A arqueologia da área do aterro Sanitário da região metropolitana de Curitiba, em Mandirituba, Paraná. Arqueologia 2: 1-138.

Copé, S.M. 2007. El uso de la arquitectura como artefacto en el estudio de paisajes arqueológicos del altiplano sur brazilieño, Rio Grande do Sul. Revista de Arquelogía 2: 15-34

Copé, S.M. \& J.D. SALDANHA. 2002. Em busca de um sistema de assentamento para o Planalto Sul-Rio-Grandense: escavaçōes no Sítio RS-AN-03, Bom Jesus, RS. Pesquisas Antropologia 58: 107-20.

Criado, F., C. Gianotti \& P. Mañana. 2006. Before the barrows: forms of monumentality and forms of complexity in Iberia and Uruguay, in L. Šmejda (ed.) Archaeology of burial mounds: proceedings of the EAA 9th annual meeting, Saint-Petersburg 2003 (Dryada Archeologica series): 38-51. Plze: Department of Archaeology, University of West Bohemia.
DE MASI, M.A.N. 2005. Relatório final. projeto de salvamento arqueológico usina hidrelétrica de Campos Novos. Florianópolis, Brazil.

- (ed.) 2006. Xokleng 2869 a.C. As terras altas do sul do Brasil. Tubarão: Editora Unisul.

DE SouZA, J.G. 2007. Significados da morte: interpretando as estruturas funerárias de Pinhal da Serra (RS) e Anita Garibaldi (SC). Anais do XIV Congresso da Sociedade de Arqueologia Brasileira (CD-ROM).

DENEVAN, W.M. 2001. Cultivated landscapes of native Amazonia and the Andes. Oxford: Oxford University Press.

DieTler, M. 2001. Theorizing the feast: rituals of consumption, comensal politics, and power in African contexts, in M. Dietler \& B. Hayden (ed.) Feasts: archaeological and ethnographic perspectives on food, politics and power: 65-114. Washington (DC): Smithsonian Institution Press.

DilleHAY, T.D. 1995. Mounds of the social death: Araucanian funerary rites and political succession, in T. Dillehay (ed.) Tombs for the living: Andean mortuary practices: 281-313. Washington (DC): Dumbarton Oaks.

- 2004. Social landscape and ritual pause: uncertainty and integration in formative Peru. Journal of Social Archaeology 4: 239-68.

- 2007. Monuments, resistance and empires in the Andes: Araucanian ritual narratives and polity. Cambridge: Cambridge University Press.

Dreyfus, S. 1972. Los Kayapo del norte de Brasil. México: Instituto Indigenista Interamericano.

FLeming, A. 1973. Tombs for the living. Man 8: 177-93.

IRIARTE, J. 2006. Landscape transformation, mounded villages, and adopted cultigens: the rise of early Formative communities in south-eastern Uruguay. World Archaeology 38: 644-63.

- 2007. New perspectives on plant domestication and the spread of agriculture in the Americas, in $\mathrm{T}$. Denham, J. Iriarte \& L. Vrydaghs (ed.) Rethinking agriculture: archaeological and ethnoarchaeological perspectives (One World Archaeology 51): 167-88. Walnut Creek (CA): Left Coast Press.

- n.d. Phytolith analysis of ceramic sherds' residues from site PM01, ElDorado, Misiones, Argentina. Manuscript on File. Archaeobotany Laboratory, Department of Archaeology, University of Exeter.

IRIARTE, J. \& H. BeHLING. 2007. The expansion of Araucaria forest in the southern Brazilian highlands during the last 4000 years and its implications for the development of the Taquara/ Itararé Tradition. Environmental Archaeology 12: 115-27. 


\section{José Iriarte, J. Christopher Gillam \& Oscar Marozzi}

Iriarte, J., O. MarozZi \& C. Gillam. 2007. Rivers of encounters: the cultural and environmental history of the Paraná River. Project report of survey and excavations at the ElDorado enclosure complex, Misiones, Argentina. Submitted to Committee for Research and Exploration, National Geographic Society.

Kertzer, D.I. 1988. Ritual, politics, and power. New Heaven (CT): Yale University Press.

LÓPEZ, J.M. 2001. Las estructuras tubulares (cerritos) del litoral Atlantico uruguayo. Latin American Antiquity 12: 231-55.

MabildE, P.F. 1983. Apontamentos sobre os indígenas selvagens da nação Coroados dos matos da província do Rio Grande do Sul. São Paulo: IBRASA/INL; Brasília: Fundação Nacional Pró-Memória.

Maniser, H.H. 1930. Les Kaingang de São Paulo. Proceedings of the $23^{\text {rd }}$ International Congress of Americanists, New York 17-22 September 1928: 760-91.

MaYbury-Lewis, D. 1974. Akwé-Shavante society. New York: Oxford University Press.

- 1979. Dialectical societies: the Gê and Bororo of central Brazil. Cambridge (MA): Harvard University Press.

Menghin, O.F. 1957. El poblamiento prehistórico de Misiones. Anales de Arqueología y Etnologia XII: 19-40.

Metraux, A. 1934. El estado actual de nuestros conocimientos sobre la extensión primitiva de la influencia guarani y arawak en el continente sudamericano. Actas y trabajos cientificos del $25^{\circ}$ Congreso Internacional de Americanistas (La Plata 1932): 181-90. Buenos Aires.

- 1946. The Caingang, in J.H. Steward (ed.) Handbook of South American Indians. Volume 1: the marginal tribes: 445-77. Washington (DC): Smithsonian Institution.

Nimuendajú, C. 1939. The Apinayé (Anthropological series 8). Washington (DC): Catholic University of America Press.

- 1942. The Serente (Publications of the Frederick Webb Hodge Anniversary Publication Fund 4). Los Angeles (CA): Southwest Museum.

NoELli, F. 1998. The Tupi: explaining origin and expansions in terms of archaeology and of historical linguistics. Antiquity 277: 648-63.

- 2000. A ocupação humana na região sul do Brasil: arqueologia, debates e perspectivas. Revista USP (Universidade de São Paulo) 44: 218-69.

- 2005. Rethinking stereotypes and the history of research on Jê populations in South Brazil, in P. Funari, A. Zarankin \& E. Stovel. (ed.) Global archaeological theory: contextual voices and contemporary thoughts: 166-90. New York: Springer.
NordenskiÖld, E. 1930. Ars Americana: l"archéologie du bassin de l'Amazone. Paris: C. van Oest.

OTTONELlo, M. \& A.M. LORANDI. 1987. Introducción a la arqueología y etnología. Buenos Aires: EUDEBA.

PAUlA, J.M. 1924. Memória sobre os Botocudos de Paraná e Santa Catarina organizada pelo Serviço de Proteção dos Selvícolas. Anais do 200 Congresso Internacional de Americanistas 1: 117-37.

Prous, A. 1992. Arqueologia Brasileira. Brasilia: Editora da Universidade de Brasília.

- 1999. Agricultores de Minas Gerais, in M.C. Tenório (ed.) Pré-história da Terra Brasilis: 346-58. Rio de Janeiro: Editora da Universidade Federal Rio de Janeiro.

RENFrEW, C. 1973. Before civilization. London: Jonathan Cape.

SALDANHA, J.D.M. 2005. Paisagem, lugares e cultura material. Unpublished MA Dissertation, Pontificia Universidade Católica do Rio Grande do Sul, Porto Alegre, Brazil.

SAUNDERS, R. 2004. Stratigraphy at the Rollins Shell Ring Site: implications for ring function. The Florida Anthropologist 57(4): 249-70.

SCHADEN, F. 1958. Xokléng e Kaingang. Revista de Antropologia 6(2): 105-12.

SCHMITZ, P.I. \& I.I. BECKER. 1991. Os primitivos engenheiros do planalto es suas estructuras subterrâneas: a Tradição Taquara, in Arqueologia Pré-histórica do Rio Grande do Sul: 251-93. Porto Alegre: Mercado Aberto.

Schmitz, P. I., J.H. Rogge, A.O. Rosa \& M.V. Beber. 1998. Aterros indígenas no Pantanal do Mato Grosso do Sul (Pesquisas Antropologia 54). São Leopoldo, Brazil: Instituto Anchietano de Pesquisas.

SEEgER, A. 1981. Nature and society in central Brazil. The Suya Indians of Mato Grosso. Cambridge (MA): Harvard University Press.

Wachnitz, G.A. 1984. Prehistoria Altoparanaense Preguarani. Misiones, Argentina: Imprenta Seyfried.

Weninger, B., O. Joris \& U. DANZEGLOCKe. 2004. Calpal- the Cologne radiocarbon CALibration and PALaeoclimate research package. Available at http://www.calpal.de.

Werner, D. 1984. Amazon journey; an anthropologist's year among Brazil's Mekranoti Indians. New York: Simon \& Schuster.

WUST, I. \& C. BARRETO. 1999. The ring villages of Central Brazil. A challenge for Amazonian archaeology. Latin American Antiquity 10 (1): $3-23$. 